\title{
News Coverage of Romahurmuzy Arrest: A Critical Discourse Analysis of Three National Online Media
}

\author{
Mohammad Isa Gautama \\ Sociology Department \\ Faculty of Social Science \\ Universitas Negeri Padang \\ Padang, Indonesia \\ migatama@fis.unp.ac.id
}

\begin{abstract}
Romahurmuziy, Chairman of the United Development Party (PPP) was arrested during a sting operation (Operasi Tangkap Tangan/OTT) on March 15, 2019 by the Corruption Eradication Commission (KPK) in Surabaya. He is suspected of committing corruption in form of bribery in buying and selling position at the local level. This event shocked the public because Romy (as his nickname) was known as an influential politician and had a very close position to power. On the day of the incident, online media massively covered the news. This research uses Critical Discourse Analysis (CDA) through Robert N. Entman version of Framing Analysis approach. Data was collected from three news sources from three national online media (republika.co.id, kompas.com and vivanews.co.id). The central questions of the study are: What is the process of news selection and high-lighting on certain aspects of the news in each media? Secondly, what position was chosen based on the reporting of Romahurmuziy case regarding the current corruption eradication agenda in Indonesia? The main finding of the research is that vivanews.com tends to aggressively attack Romy through his reporting. Meanwhile, republika.co.id tries to reveal the other side of the topic of the news, while kompas.com is objective enough to cover this case by the news.
\end{abstract}

Keywords---news coverage; corruption; on-line media; framing analysis; media position

\section{INTRODUCTION}

The chairman of the United Development Party (PPP) Romahurmuziy was arrested during a sting operation (OTT) in East Java by he Corruption Eradication Commission (KPK), March, 15, 2019. The Corruption Eradication Commission (KPK) officially named Romy, an associate of President Joko "Jokowi" Widodo — who is seeking a second term in office at the moment of arrest - as suspect in a bribery case on 16 March 2019 after the anticorruption body arrested him in Surabaya, East Java the day before. According to reports, Romy was among five arrested in a sting operation by the KPK during an illicit transaction in the East Java city of Sidoarjo at 9am today. Romy is a close collague of President Joko Widodo, who has proved decisive in steering PPP to join the government's coalition in 2016 after he replaced former Religious Affairs Minister Suryadharma Ali — who was prosecuted for corruption in 2014 — as the Islam-based party’s chairman (en.tempo.co, 15 March 2019).

Based on Romy position, who is a main supporter of the iincumbent President, Joko Widodo, it is very interesting and important to examine how does the position of the media, especially the online media in reporting the case. The urgency of this research to be done is essential since the event of the case is so close to the agenda of General Election on April, 17, 2019. It is important to analyze the influence of bad news which produced from every person/political party/political group who get involved in the contestation. It has been known that Joko Widodo was one of the consestants. Another contestant was Prabowo Subianto.

Through the perspective of political-media studies, Tapsell (2017) concludes that since the 2009 General Election the influence of oligarchs has been formed in instilling their political influence through the media they have. The owner of media, who are also close to power, try to choose and frame their news for their benefit. Furthermore, the political economy perspective most clearly articulates the view that the system of ownership is central to understanding of media content. In addition, the media are also capable determine what news will be delivered to the public, however more than that, framing has the power on the power to determine what news will be reframed and reinterpreted to the readers (McCullagh, 2002:36).

Regarding the efforts to fight corruption, Smilov (2007) mentions that there are six elements that will become a powerful force as a catalyst for the anti-corruption movement. The six elements are the media, politicians, judicial institutions (judiciary), police and prosecutors, civil society / NGOs, and entrepreneurs/business people. These six elements must be able to work together, have the main agenda in each program to not only eradicate corruption cases, but also be able to implement a preventive system (system that is able to prevent) in their respective institutions. Moving on from this, without denying the other five elements, the media is one of the spearheads which is undoubtedly it is affected the anticorruption movement. Whatever is reported and published by the media, regarding anti-corruption themes, is a means of education for the public about the dangers of corruption. 
Moreover, the media has four functions, one of which is as social control in society.

\section{MethodS}

This research based on the constructionist paradigm whose was mainly pioneered by Berger, Luckman, and Erving Goffman. Berger and Luckman stated that social reality consists of three kinds; namely subjective reality, objective reality and symbolic reality. Objective reality is reality that is formed from experience in the objective world that is outside of the individual self, and this reality is considered as reality. Symbolic reality is a symbolic expression of objective reality in various forms; meanwhile, subjective reality is objective and symbolic reality into individuals through the process of internalization (Subiakto 1997, in Bungin, 2012).

The main thesis of Berger is that people and society are continually dialectical, dynamic and plural products. Society is nothing but a human product, but continually has a backlash against its producers (Eriyanto, 2002: 13-14). According to Berger, reality is neither formed scientifically, nor is something passed down by God. But instead, it was formed and constructed. With this kind of understanding, reality is multi-faced/plural. Every person can have different construction of a reality (Eriyanto, 2002: 15).

Sobur (2004) stated, framing analysis, content analysis of agenda setting and social semiotic analysis belong to the constructivism paradigm group which believes that whatever is packaged and displayed by the media is the result of the construction and interference of the actors behind it, in this case journalists and journalists as news processors. Furthermore, according to Sobur (2004: 162), framing analysis is an approach to find out how the perspective or perspective used by journalists when selecting issues and writing news.

Moreover, framing analysis can be simplify as an analysis to find out how reality (events, actors, groups, or whatever) is framed by the media, the framing is of course through the construction process (Eriyanto, 2002: 3). Eriyanto explained in ore detail, social reality is interpreted and constructed with certain meanings. Events are understood by certain formations. The result, media coverage or on certain sides or interviews with certain people. All these elements are not only part of technical journalism, but indicate how events are interpreted and displayed.

The purpose of the research is to find out and understand to what extend the actors behind writing news frame and construct the reality of the existing news. The framing analysis model chosen in this study is Robert Entman's version. Entman's framing emphasizes on how the selection and highlighting of certain aspects is reflected in the reality captured by the media coverage.

Framing Analysis version of Robert N. Entman is divided into four elements, first is Define Problems, it is about how an event is seen as what, second, Diagnose Causes (estimating the cause of the problem), estimating the problem or the source of the problem, third, Make Moral Judgment (making moral choices ) and what moral values you want presented in the news, and fourth, Treatment Recommendation (emphasizing resolution), which is the resolution of what you offer to solve the conflict (Eriyanto, 2002: 223).

Based on the background, phenomena, problems, basic concepts, and relevant theories above, it can be formulated that the problem will be examined in this study, namely how the on line media displays, packages and constructs straight news about sting operation conducted by the Corruption Eradication Commission of the Republic of Indonesia to the PPP chairman, Romahurmuziy, on March 15, 2019.

\section{RESULTS AND DISCUSSION}

To find out how the news about the process of catching hands to Romy was framed by the media, the researchers took the text of the news from three media on line. The three media were chosen based on the assumption that viva.co.id is a media owned by Aburizal Bakrie (id.vivagroup.id), a politician from the Golongan Karya party who during the 2019 General Election tended to be more pro to Joko Widodo's competitor, namely Prabowo Subianto (www.merdeka.com). On other side, republika.co.id was chosen based on the argument that this media is owned by Erick Tohir, political ally and the chairman of National Champaign Team (TKN) of Joko Widodo (tirto.id). On the other hand, kompas.com was chosen because based on media ownership, this online media is more neutral because the owner, Jakob Oetama is not affiliated with any political party.

The data collection technique is by selecting straight news that was uploaded on March 15, 2019 in the three online media. As public known, on March 15, 2019 was the day when the Corruption Eradication Commission conducted sting operation to Rommy at a hotel in Surabaya. The author deliberately selected the three earliest news in each of the media which covered the arrest. The researcher argues that three earliest news will be able to reflect the tone and choice of highlighting certain issues or perspectives from this case.

TABLE I. LIST OF NEWS TITLE OF THREE ONLINE MEDIA

\begin{tabular}{|c|c|c|c|}
\hline No. & Media & News Tittle & $\begin{array}{l}\text { Upload } \\
\text { Time }\end{array}$ \\
\hline 1 & republika.co.id & $\begin{array}{l}\text { a. KPK TangkapTangan } \\
\text { Petinggi Politik. } \\
\text { b. Polda Jatim } \\
\text { Benarkan Adanya } \\
\text { Pemeriksaan Ketum } \\
\text { PPP. } \\
\text { c. PPP Belum Mau } \\
\text { Berkomentar Soal } \\
\text { OTT KPK. }\end{array}$ & $\begin{array}{l}\text { 11:57. A.M } \\
\text { 12:14. A.M } \\
\text { 13:06. A.M }\end{array}$ \\
\hline 2 & kompas.com & $\begin{array}{l}\text { a. KPK Dikabarkan } \\
\text { Tangkap Ketua } \\
\text { Umum Parpol } \\
\text { b. Dikabarkan } \\
\text { Ditangkap KPK, } \\
\text { Ketua Umum Parpol } \\
\text { Diperiksa di Polda }\end{array}$ & $\begin{array}{l}\text { 11:26. A.M } \\
\text { 11:39. A.M }\end{array}$ \\
\hline
\end{tabular}




\begin{tabular}{|c|c|c|c|}
\hline & & $\begin{array}{l}\text { Jatim } \\
\text { c. Ketua KPK Benarkan } \\
\text { Ketua Umum PPP } \\
\text { Romahurmuziy } \\
\text { Terjaring OTT }\end{array}$ & 11:44. A.M \\
\hline 3 & viva.co.id & $\begin{array}{l}\text { a. KPK Tangkap Ketua } \\
\text { Umum Partai Politik } \\
\text { b. KPK Tangkap Ketua } \\
\text { Umum Partai, } \\
\text { Kabarnya } \\
\text { Romahurmuziy } \\
\text { c. KPK Tangkap Ketua } \\
\text { Umum PPP, } \\
\text { Romahurmuziy }\end{array}$ & $\begin{array}{l}\text { 11:09. A.M } \\
\text { 11:39. A.M } \\
\text { 11:46. A.M }\end{array}$ \\
\hline
\end{tabular}

The technique of data analysis in this research is to read in generally and at the same time carefully report the generalization each of news. As said Eriyanto (2002: 186), Entman sees framing in two macro dimensions: issue selection and emphasis or highlighting certain aspects of reality / issue. Highlighting is the process of making information more meaningful, more interesting or more remembered by the public. Furthermore, in Entman's conception, framing basically refers to the provision of definitions, explanations, evaluations, and recommendations in a discourse to emphasize a particular frame of mind for the event being discussed (Eriyanto, 2002: 188).

As we have seen in the table above, there are a total of 9 news titles that were used as the object of research analysis, whereas 3 of it downloaded each from republika.co.id, kompas.com, and viva.co.id. Each story is grouped according to the online media that uploads the news. Next, every single news is discussed based on four aspects of Entman's version of framing, namely Problem Identification, Causal Interpretation, Moral Evaluation, and Treatment Recommendation.

\section{A. Framing of republika.co.id}

Problem Identification. As a media owned by main supporter Joko Widodo, breaking news coverage on the arrest was not intensified and comprehensively propagated by republika.com. From headlines, it can be seen; the media does not mention names, only the position (General Chairperson) and party name (PPP). It implies that this media does not want to justify sharply the personal identity of the perpetrators of corruption. In terms of content, in the first news, $K P K$ Tangkap Tangan Petinggi Politik (The Corruption Eradication Commission Commissioner Arrests a Political Party Officials in Sting Operation), a statement from the KPK chairman, Agus Rahardjo, who asked journalists to be patient waiting for a press conference within 24 hours after arrest event. In the second news, Kapolda Jatim Benarkan Adanya Pemeriksaan Ketum PPP (East Java Police Supreme Leader Justifies Examination of PPP Chairperson), contains of the statement of the Supreme Leader of the East Java Police who confirmed the examination but directed the journalists to ask the KPK leaders about the full version. While on the third news, $P P P$
Belum Mau Berkomentar Soal OTT KPK (PPP Does Not Want to Comment on the Sting Operations of the KPK), according to the title, the party's top officials are reportedly not willing to comment anything important to public yet.

Causal Interpretation. There was no concrete confirmation about the position of republika.co.id to Romy as the cause of the uproar. There is not even one news among the three news that made the public aware that Romy has betrayed the mandate of all elements of the nation to be the foremost part of voicing and practicing democratic values that are spared from corrupt actions.

Moral Evaluation. It is not contrary at all from the above analysis, republika.co.id is very minimal in placing moral standards as a reference in reporting news regarding Romy's arrest. There was an impression that this media was not trying to suppress and said that what Romy had done was despicable. There was no assertion that Romy was morally deviant and should be punished severely and injure the government efforts which is aggressively combating corruption.

Treatment Recomendation. Republika.co.id does not show any symbolic appeal or suggestion through its coverage of the Romy case. Recommendations are expected to expressly declare the war on corruption is being 'squeezed' by 'unimportant angle in the form of quotations from informans that hang and are not sharp. The substance that corruption is a real danger and threatens the whole life of the nation is not reflected in the news regarding the capture of Romy corruption case.

\section{B. Framing of kompas.com}

Problem Identification. In the first new with titled $K P K$ Dikabarkan Tangkap Ketua Umum Parpol (KPK Reportedly Arrested a Party Chairperson), kompas.com seemed to be careful in highlighting problem identification. In the news content, the perpetrator's name was mentioned, kompas.com stated that the investigation was still ongoing and there had been no official statement from the KPK official. While in the second news, Dikabarkan Ditangkap KPK, Ketua Umum Parpol Diperiksa Polda Jatim (Reportedly Arrested by the KPK, a Chairperson of a Political Party Examined at the Regional Police), quoted based on a KPK investigator statement that the examination was ongoing and had not yet to decide the official legal status for the actor. While on the third news, Ketua Umum KPK Benarkan Ketua Umum PPP, Rohamurmuziy Terjaring OTT (The Commision Accused the Chairperson of PPP Romahurmuziy arrested) is explicitly explain by kompas.com to the public about the perpetrators of corruption cases captured by the KPK through the disclosure of actor identity and his political position. Through a quote from the Chairperson of the Corruption Eradication Commission, Agus Rahardjo, it was also explained about the location of the arrest and further action after the arrest.

Causal Interpretation. Although it is not too strict, kompas.com is brave enough to bring up the symbol in the news discourse that Romy is one of the causes of chaos in the perpetrators of corruption and getting a proportional 'reward' in the form of arrests in sting operations by the KPK. 
Moral Evaluation. Almost as the same as the discussion from the perspective of causal interpretation, kompas.com is quite sharp in highlighting the discourse that Romy is morally necessary to be punished by the public through transparent reporting. This is reflected mainly in the third news.

Treatment Recomendation. Based on an analysis of the three kompas.com news, treatment recommendations are not apparent. This may be due to the nature of breaking news that reports what is found in the earliest time the arrest occurred. Kompas.com has not described the strong opinion about what public has to do other than just a news coverage regarding the arrest process and statements from relevant officials.

\section{Framing of viva.co.id}

Problem Identification. Viva.co.id based on the first news of its coverage of the Romy case, KPK Tangkap Ketua Umum Partai Politik (KPK arrests the Chairman of Political Party) impressed to describes the chronology carefully. The media only reports the chronology of the arrest, location and time of arrest, and cites a statement from a spokesman of the East Java Regional Police. Meanwhile, in the second, KPK Tangkap Ketua Umum Partai, Kabarnya Romahurmuziy (KPK Arrests Political Party Chairman, Reportedly Romahurmuziy) and third news, KPK Tangkap Ketua Umum PPP, Romahurmuziy (KPK Arrests Chairman of PPP, Romahurmuziy) the media which is owned by President Joko Widodo competitor clearly stated Romy's Political Party name in the headline. The difference is, in the first news the initials of the perpetrators (MR) are published, while in the third news the full name of Romahurmuziy is clearly stated. The third news also confirmed the information from PPP party's Deputy Secretary General who claimed did not hear of the arrest case yet.

Causal Interpretation. In terms of news length, viva.co.id covers a shorter news size than the other two media. Despite trying to explicitly justify Romy and the Party led by Romy, viva.co.id was seen trying to cover the arrest incident carefully. However, compared to republika.co.id coverage in general, there was still an effort to influences public opinion that Joko Widodo's camp, which in this case was represented crime done by Romy, had made a mistake and caused the public uproar.

Moral Evaluation. Due to its short size, the three earliest news covering Romy arrest are still dominated by clarity of arrest information, the name of the perpetrator and affiliation, and efforts to disclose the characteristics of the case and clarity of the perpetrator's status. In this case, there has not yet been a moral evaluation of the coverage of this news coverage, although there is an implicit effort to direct the perpetrators and the cause of public upheaval to Romy and PPP as supporters of Joko Widodo.

Treatment Recomendation. Based on a serious analysis, it was found that three news viva.co.id had very little additional information besides straight news. Arrest information is only supported by a number of facts and statements from related parties. This implies that this media seems to provoke readers to follow the news further. From the perspective of recommendation treatment, it can be said that vica.co.id has very little clues.

\section{CONCLUSION}

Based on constructivism perspective, the media is a product of the ideology and socio-cultural beliefs of its managers and owners. Entman (2010: 337) says that the media bias is getting stronger when various interests scramble for influence to win the hearts of the public. Media that have a high awareness of social responsibility will be able to withstand that bias on condition that they always evaluate and 'clean up' the potential threats of any interests that easily come unexpectedly.

From the results of the study it can be concluded that online media in Indonesia is still significant with bias in political interests. This bias is even more apparent when related to the phenomenon of the General Election event which is only a month away from the Romy booming case in the mass media on March 15, 2019. In this context, republika.com is trying not to overly politicize the Romy case. In the case of the inclusion of identity there is an attempt to disguise the identity. Likewise in terms of causal interpretation, this media does not seem to form a public opinion that Romy has caused a criminal act of corruption. In other hand, Kompas.com trying to be neutral, reflecting in the analysis of problem identification and moral evaluation. Meanwhile viva.co.id, although covering the coverage of Romy arrest in very smooth manner, in the second and third news appear to be trying to highlight the identity of the perpetrators and implicitly direct the public mind to blame Romy as the cause of an extra-ordinary criminal act.

Moving forward from now, more comprehensive research needs to be done on the extent to which new media plays its role in participating in political contestation, not only in the General Election event, but also in daily political dynamics. It is important to examine, in what extend the media and press in Indonesia are able to survive and to not dissolve in the bias of certain (political) interest.

\section{REFERENCES}

[1] Bungin, Burhan, ed,. Metodologi Penelitian Kualitatif: Aktualisasi Metodologis ke Arah Ragam Varian Kontemporer. Depok: PT. Rajagrafindo Persada. 2012.

[2] Entman, Robert M. Framing Media Power. A chapter in Doing News Framing Analysis. New York and London: Routledge. 2010.

[3] Eriyanto. Analisis Framing: Konstruksi, Ideologi, dan Politik Media. Yogyakarta: LKiS. 2002.

[4] McCullagh, Ciaran. Media Power: a Sociological Introduction. London: Palgrave. 2002.

[5] Smilov, Daniel and Jurij Toplak (eds.). Political Finance and Corruption in Eastern Europe: The Transition Period. Hampshire England: Ashgate Publishing Limited. 2007.

[6] Sobur, Alex, Analisis Teks Media. PT Remaja Rosdakarya, Bandung, 2004.

[7] Tapsell, Ross. Media Power in Indonesia: Oligarchs, Citizens and the Digital Revolution. London and New York: Rowman \& Littlefield, (Series Media, Culture and Communication in Asia-Pacific Societies). 2017. 
[8] Retrieved from: https://en.tempo.co/read/1185579/kpk-confirms-arrestof-romahurmuziy-in-east-java-ott

[9] Retrieved from: https://id.vivagroup.co.id/tentang-kami/profilperusahaan/

[10] Retrieved from: https://www.merdeka.com/aburizal-bakrie/

[11] Retrieved from: https://tirto.id/para-konglomerat-di-belakang-jokowidan-prabowo-pada-pilpres-2019-c1kn 